\title{
Fracture promotion versus prevention: the cuticular breakage zone at the trunk autotomy plane of the scaleworm Harmothoe impar (Annelida: Polynoidae)
}

\author{
I.C. Wilkie \\ Institute of Biodiversity, Animal Health and Comparative Medicine, University of Glasgow, \\ Glasgow G12 8QQ, Scotland. \\ E-mail:iain.wilkie@glasgow.ac.uk
}

\begin{abstract}
Although it is well known that polynoid scaleworms can autotomise various appendages and posterior portions of the trunk, this is a neglected component of their behavioural repertoire. Autotomy in polynoids and other annelids necessitates the fracture of the external cuticle, which is a collagenous structural material. The aim of this investigation was to gain insight into the mechanism by which the cuticle is fractured during trunk autotomy in Harmothoe impar using light and electron microscopy. At autotomy the cuticle fractures at a pre-formed breakage zone which passes through a cuticular thickening consisting of an internal apodeme and external ridge. It is hypothesised that cuticular fracture is initiated by the contraction of specific groups of longitudinal muscle fibres, which results in the concentration of tensile stress at the basal edge of the breakage zone. The risk of accidental fracture of the breakage zone is reduced by several morphological features including the external ridge, which prevents stress concentration at the external edge of the breakage zone, and the undulating profile of the breakage zone, which increases its resistance to shearing forces.

How to cite this article: Wilkie I.C. 2020. Fracture promotion versus prevention: the cuticular breakage zone at the trunk autotomy plane of the scaleworm Harmothoe impar (Annelida: Polynoidae) // Invert. Zool. Vol.17. No.1. P.76-92. doi: 10.15298/invertzool.17.1.08
\end{abstract}

KEY WORDS: Annelid cuticle, autotomy, force transmission, fracture mechanism, Polynoidae, tendon cells, tonofilaments.

\section{Стимуляция разрыва или его предотвращение: зона кутикулярного разлома при автотомии у Harmothoe impar (Annelida: Polynoidae)}

\section{И.С. Уилки}

Institute of Biodiversity, Animal Health and Comparative Medicine, University of Glasgow, Glasgow G12 8QQ, Scotland.

E-mail: iain.wilkie@glasgow.ac.uk

РЕЗЮМЕ: Хотя хорошо известно, что большинство кольчатых червей семейства Polynoidae способно к автотомии различных выростов и заднего конца тела, до сих пор остаются плохо изученными глубинные механизмы этого процесса. Автотомия 
у полиноид и других аннелид неизбежно приводит к разрывам внешней кутикулы, которая представляет собой коллагеновую структуру. Целью настоящей работы является раскрытие механизмов, лежащих в основе разрыва кутикулы при автотомии участка туловища на примере Harmothoe impar, с использованием методов световой и просвечивающей электронной микроскопии. Перед разрывом в толще кутикулы формируется зона разлома, которая проходит сквозь всю толщу кутикулы, включая внутреннюю аподему и внешний край. На основе полученных данных было выдвинуто предположение, что кольцевой разрыв кутикулы инициируется сокращением специальных групп продольных мышц, в результате которого создается напряжение на базальном крае зоны разлома. Риск случайного разрыва зоны разлома сводится к минимуму благодаря наличию нескольких морфологических особенностей, среди которых наличие внешнего гребня, предотвращающего возникновение напряжения на наружном крае зоны разлома. Вторая важная морфологическая особенность - это волнистая структура зоны разлома, которая повышает устойчивость зоны к срезающей силе.

Как цитировать эту статью: Wilkie I.C. 2020. Fracture promotion versus prevention: the cuticular breakage zone at the trunk autotomy plane of the scaleworm Harmothoe impar (Annelida: Polynoidae) // Invert. Zool. Vol.17. No.1. P.76-92. doi: 10.15298/ invertzool.17.1.08

КЛЮЧЕВЫЕ СЛОВА: кутикула аннелид, автотомия, сила переноса, механизм разрыва, Polynoidae, сухожильные клетки, тонофиламенты.

\section{Introduction}

Scaleworms belonging to the family Polynoidae occur worldwide, from the tropics to the Arctic and Antarctic, and from the intertidal to the hadal zones (Beesley et al., 2000; Paterson et al., 2009). They are present on and in a broad range of substrata, they have colonised various chemosynthetic-based habitats, including hydrothermal vents and whale carcasses (Zhang et al., 2017), and 25\% of the 891 known species in the family form commensal relationships with a wide diversity of host taxa (Martin, Britayev, 1998, 2018). However, despite their obvious evolutionary success, knowledge of polynoid biology is patchy.

One component of their behavioural repertoire that has been largely neglected is autotomy - the defensive and active detachment of anatomical structures. It is well known that many polynoids have the capacity to discard parapodia, elytra, cirri and other sensory appendages, as well as posterior portions of the trunk. Taxonomic descriptions provide ample evidence for this aptitude (see, e.g. Moore, 1910; López, San
Martín, 1996; Nishi, Tachikawa, 1999; Zhang et al., 2018), Moore's comments on Harmothoe fragilis being particularly pertinent: “... this species is so fragile that not a single perfect example is known. Most of the [considerable number of] specimens are anterior ends of fifteen to twenty segments without elytra or cirriform appendages." In view of the apparent prevalence of the phenomenon, it is surprising that most available information on polynoid autotomy is to be found in only three papers: Daly (1973) described the morphology of the trunk autotomy plane in Harmothoe imbricata and speculated about the autotomy mechanism; the present author investigated the mechanism by which the external collagenous cuticle is fractured during autotomy of the elytra in Alentia gelatinosa (Wilkie, 2011); and the employment by $H$. imbricata of scale and trunk autotomy (and luminescence) in response to decapod crustacean predators was studied by Livermore $e t$ al. (2018).

The work described herein complements that of Wilkie (2011), since it deals with the mechanism of cuticular fracture at the trunk 
autotomy plane of a polynoid. All autotomy planes transect a number of different anatomical components, which always include structural materials, such as the exocuticle of arthropod limbs (McVean, 1973; Schindler, 1979; Shultz, 2000) or the dermis of the skin and the bone of the spinal column in vertebrate tails (Wake, Dresner, 1967; Sheppard, Bellairs, 1972; Sanggaard et al., 2012). Since an important role of structural materials is to resist mechanical forces, autotomy is always facilitated by either a constitutive reduction in the cross-sectional area of such materials, resulting in a preformed zone of weakness, or by a mechanism that reduces the mechanical resistance of the material at the time when autotomy is provoked. The latter can be achieved either through an endogenous loss of tensile strength, as occurs in the mutable collagenous tissue at echinoderm autotomy planes (Wilkie, 2001), or through the application of a muscular force that is sufficient to tear the material apart, as occurs at the autotomy planes of arthropod limbs (McVean, 1973; Shultz, 2000) and vertebrate tails (Wake, Dresner, 1967; Sheppard, Bellairs, 1972).

The external cuticle that overlies the epidermis of the annelid integument is a structural material that is transected during autotomy. At the elytrophoral autotomy plane of the polynoid Alentia gelatinosa, fracture of the cuticle is initiated by both direct and indirect transmission of muscular force to a specialised breakage zone in the cuticle (Wilkie, 2011). The different microstructural organisation of the epidermis and adjacent structures at the breakage zone of the trunk cuticle (Daly, 1973) indicates that it cannot be fractured by the same mechanism at autotomy. The aim of this investigation was therefore to gain insight into the mechanism of trunk cuticular fracture in polynoids by analysing the morphological features of the epidermal region of the trunk autotomy plane of Harmothoe impar using light and transmission electron microscopy.

The trunk autotomy planes of polynoids are located at the intersegmental grooves in the body wall, the primary function of which is to facilitate flexion of the body wall when the trunk bends during locomotion and other activities. As will be shown below, the cuticle fractures at a breakage zone consisting of material that is likely to have lower tensile strength than normal cuticle. The presence of such a breakage zone at the hinge area of the cuticle raises the danger that during normal movement this zone may be subjected to tensions that fracture it inappropriately: this could occur, for example, at the convex side of a bending trunk where the cuticle is unfolding and the hinge area is stretched by opposing tensile forces. This paper describes structural features that reduce the risk of such accidental breakage.

\section{Materials and methods}

Specimens of Harmothoe impar (Johnston, 1839) were collected from intertidal rock pools at White Bay, Isle of Cumbrae, Firth of Clyde, Scotland. Animals were induced to autotomise by compressing the trunk with forceps. Autotomy was induced at a distal position and then at a more proximal position, in order to obtain pieces of trunk that consisted of three to seven segments and had a fractured autotomy plane at either end.

For light microscopy, such pieces were fixed in $10 \%$ neutral buffered formalin and embedded in paraffin wax. Parasagittal and horizontal sections $8 \mu \mathrm{m}$ thick (Fig. 1) were stained with Milligan's trichrome, which provides good differentiation between basic tissue types (Humason, 1979), picrosirius red, which distinguishes collagenous components (Montes, Junqueira, 1991), and periodic acid-Schiff, which indicates the presence of neutral 1,2 glycol-containing carbohydrates (Cook, 1990). The sections were viewed and photographed in Olympus BH-2 and CX40 microscopes (Olympus UK Ltd., Southend-on-Sea, UK).

For transmission electron microscopy (TEM), tissue pieces were fixed in 3\% glutaraldehyde in sea water, post-fixed in $1 \%$ osmium tetraoxide in sea water, and embedded in araldite. Ultrathin parasagittal sections were cut using an LKBIII 8800 ultramicrotome (LKB Instruments Ltd., Croydon, UK), mounted on Formvar-coat- 


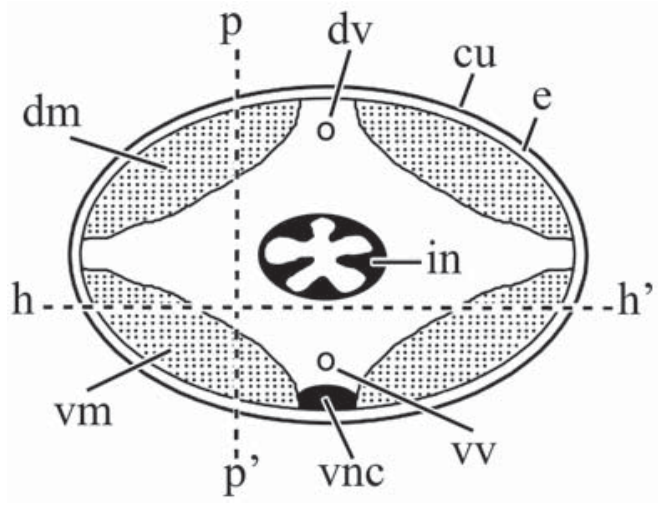

Fig. 1. Diagrammatic transverse section of the trunk of a polynoid. Not to scale.

Abbreviations: $\mathrm{cu}$ - cuticle; $\mathrm{dm}$ - dorsal longitudinal muscle; dv — dorsal blood vessel; e — epidermis; hh' example of a horizontal section plane; in - intestine; pp' example of a parasagittal section plane; vm - ventral longitudinal muscle; vnc — ventral nerve cord; vv ventral blood vessel.

Рис. 1. Схема поперечного среза через тело полиноидных червей. Без масштаба.

Обозначения: cu - кутикула; dm - дорсальные продольные мышцы; dv - досальный кровеносный сосуд; e - эпидермис; hh' - пример среза в горизонтальной плоскости; in - кишечник; рp' - пример среза в парасагиттальной плоскости; vm - вентральная продольная мускулатура; vnc - брюшная нервная цепочка; vv — вентральный кровеносный сосуд.

ed copper grids, and stained with $2 \%$ uranyl acetate in methanol and Reynolds' lead citrate. They were viewed and photographed in an FEI Morgagni 268 microscope (FEI, Eindhoven, The Netherlands).

\section{Results}

\section{Gross anatomy}

The gross anatomy of the trunk of Harmothoe impar is illustrated in Fig. 1, 2A. The outermost layers of the trunk are the external cuticle and underlying epidermis. Adjacent to the epidermis in parasagittal positions are the paired dorsal and ventral longitudinal muscles. The dorsal and ventral surfaces of the trunk exhibit two alternating types of circumferential groove: one type of groove is shallow and broad (especially in the dorsal region); the other type is deeper and narrower (Fig. 2A). The latter, which are called intersegmental grooves, de- marcate the repeating segments of the trunk and indicate the location of the trunk autotomy planes. Major structures transected by the trunk autotomy plane include the cuticle, epidermis, longitudinal muscles, intestine, ventral nerve cord, and ventral and dorsal blood vessels (Fig. 1).

\section{Light microscopy}

The cuticle comprises two layers: a thin outer epicuticle and a much thicker inner basal cuticle (Fig. 2B). The epidermis is a single layer of columnar to cuboidal cells. These include secretory cells, sensory cells, and support cells, the last type often containing pigment granules and showing a variety of cytological characteristics that reflect functional differentiation (Hausen, 2005). In parasagittal locations the epidermis is separated from the underlying longitudinal muscle by a subepidermal layer of connective tissue of varying thickness (Figs $2 \mathrm{~B}-\mathrm{D}$, 3A, B).

At the intersegmental grooves the cuticle projects internally to form a circumferential ridge or flange, which has previously been called an "apodeme" (Clark, Richardson, 1967; Daly, 1973). The salience (radial thickness) of the apodeme is greatest in dorsolateral and ventrolateral locations (Figs 2B-D, 3A, B), and least in locations between the longitudinal muscle blocks, such as below the ventral nerve cord (Fig. 2E). The cuticular breakage zone (CBZ) is discernible in sections stained by Milligan's trichrome or picrosirius red as a fine unstained, or weakly stained, line (around $1 \mu \mathrm{m}$ thick) that passes through the centre of the apodeme from its outer to inner margins (Figs 2B-E, 3A, B). The CBZ is strongly stained by periodic acid Schiff(PAS) (as is the epicuticle), in contrast to the moderate PAS staining of the other regions of the cuticle (Fig. 3C; Table 1). At the external edge of the apodeme, the CBZ does not pass through the deepest part of the intersegmental groove, but through a low central ridge, on either side of which are several smaller parallel ridges and grooves resulting in a corrugated topology (Fig. 3B). The CBZ itself is not a flat plate but has an irregularly undulating profile (Fig. 3B). 


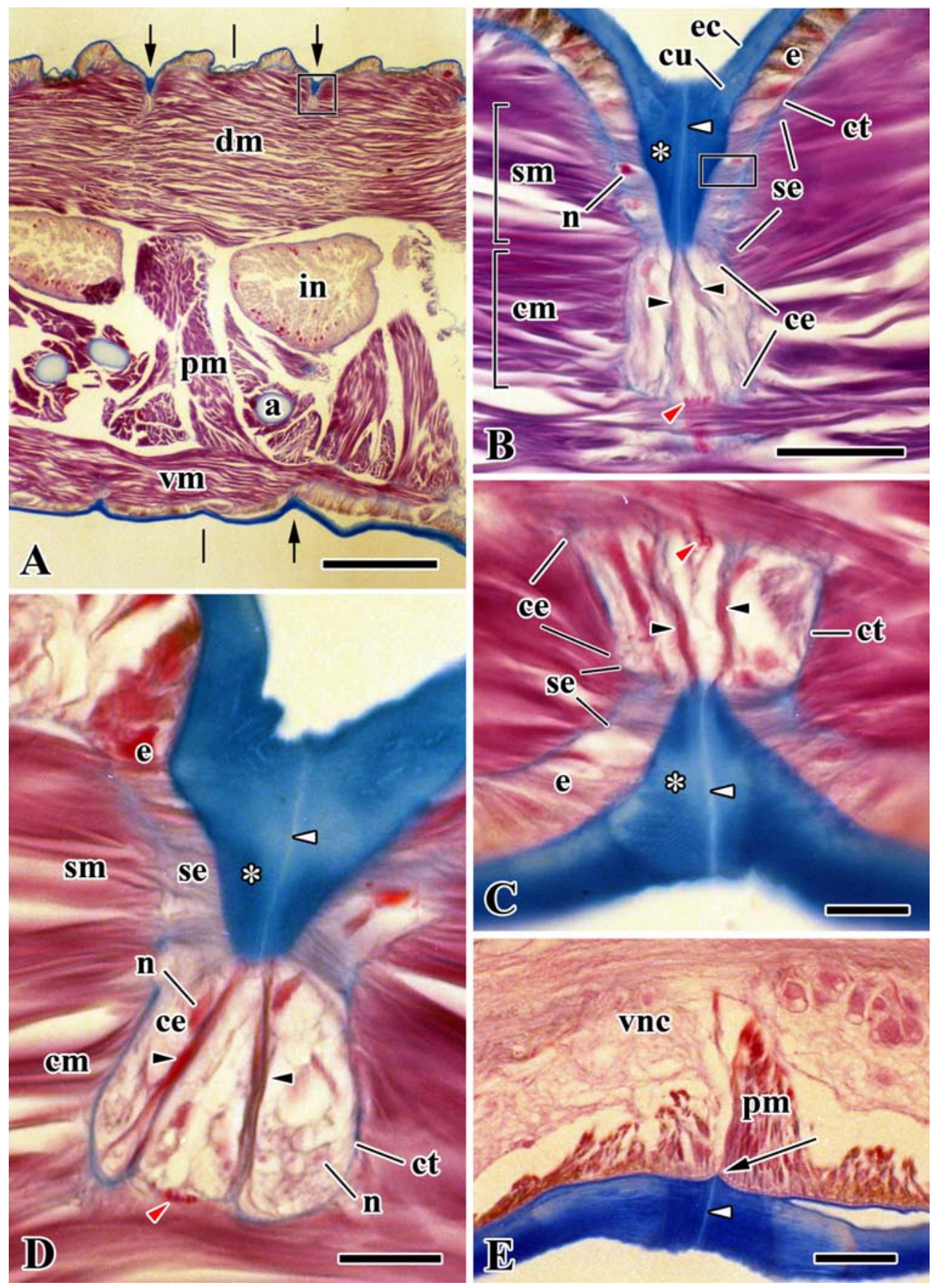

Fig. 2. Histology of the trunk cuticular breakage zone (CBZ) and adjacent structures of Harmothoe impar. All sections stained with Milligan's trichrome. In all micrographs the anterior end of the animal is towards the right; asterisks indicate cuticular apodeme; black arrowheads indicate crestal sheets of tendon cells; red arrowheads indicate circumferential acidophilic fibres; and white arrowheads indicate CBZ. A — parasagittal section of the whole trunk; dorsal side at top; arrows indicate intersegmental grooves; vertical lines indicate non-intersegmental groove; box indicates area enlarged in Fig. 2B; B - parasagittal section of dorsal CBZ 
The epidermis adjacent to the apodeme differs in appearance from that outside the intersegmental grooves. The latter is dominated by nucleated cells that overall are moderately acidophilic (i.e. stained by the acid fuchsin of Milligan's trichrome) and tend to contain dark pigment granules, whereas the epidermis adjacent to the anterior and posterior surfaces of the apodeme (which will be called the "subcrestal epidermis") is sparsely nucleated and seems to consist of densely packed parallel fibres that are weakly basophilic (i.e. stained by the aniline blue of Milligan's trichrome), though another acidophilic component is just discernible in some sections (Fig. 2B-D); they are also unstained by picrosirius red, in contrast to the strongly stained cuticle and subepidermal connective tissue (Fig. 3A, B; Table 1). These fibres extend roughly orthogonally from the apodeme to the subepidermal connective tissue. At the internal crest (i.e. apex) of the apodeme, the epidermis is inflated adaxially and in the anterior and posterior directions to form a circumferential tube with a roughly circular transverse profile (Figs 2B-D, 3A). This crestal epidermis is dominated by two circumferential- ly orientated sheets of cells that extend from the apodemal crest on the anterior and posterior sides respectively of the CBZ to the subepidermal connective tissue at the opposite, adaxial side of the epidermal tube; transverse sections of these sheets are shown in Fig. 2B-D and Fig. $3 \mathrm{~A}$. The two sheets are roughly parallel to each other or diverge slightly. The crestal sheets have both basophilic and acidophilic components (Fig. 2B-D). Other cells within the crestal epidermis are weakly stained and have a vacuolated appearance (Fig. 2D). The subepidermal connective tissue adjacent to the crestal epidermis is well developed on the anterior and posterior sides, but is much thinner on the adaxial side between the insertion points of the crestal sheets: this is particularly obvious in Fig. 2D and Fig. $3 \mathrm{~A}$. At the basal edge of the cells overlying this attenuated region there is a small cluster of intensely acidophilic, circumferentially orientated fibres (Fig. 2B-D).

Whilst the bulk of the dorsal and ventral longitudinal muscles extends continuously between segments (Fig. 2A), a superficial layer of fibres is interrupted by the apodemes. These superficial fibres are attached via the connec-

adjacent to dorsal longitudinal muscle, as indicated in Fig. 2A; box indicates approximate location of area shown in Fig. 4A; $\mathrm{C}$ - parasagittal section of ventral CBZ adjacent to ventral longitudinal muscle; $\mathrm{D}$ horizontal section of lateral CBZ adjacent to ventral longitudinal muscle; $\mathrm{E}$ - parasagittal section of ventral CBZ below ventral nerve cord; arrow indicates cuticular thickening.

Abbreviations: a — aciculum; ce — crestal epidermis; $\mathrm{cm}$ - crestal muscle fibres; $\mathrm{ct}$ — subepidermal connective tissue; $\mathrm{cu}$ — basal cuticle; $\mathrm{dm}$ - dorsal longitudinal muscle; e — non-apodemal epidermis; ec — epicuticle; in — intestine; $\mathrm{n}$ - nucleus; $\mathrm{pm}$ - parapodial musculature; se - subcrestal epidermis; sm - subcrestal muscle fibres; $\mathrm{vm}$ - ventral longitudinal muscle; vnc - ventral nerve cord. Scale bars: A $-0.4 \mathrm{~mm}$; B, E $-40 \mu \mathrm{m}$; C, D $-20 \mu \mathrm{m}$.

Рис. 2. Гистологическая организация кутикулярной зоны разлома туловища (CBZ) и прилежащих структур у Harmothoe impar. Все срезы окрашены трихромом Миллигана. На всех фотография передний конец тела животного расположен справа; звездочками обозначены кутикулярные аподемы; черными наконечниками указаны пластинки гребня сухожильных клеток; красными наконечниками указаны кольцевые периферические асидофильные волокна; белыми наконечниками указана CBZ. A - парасагиттальный срез через все тело червя; дорсальная сторона сверху; стрелками показаны межсегментные желобки; квадрат обозначает область, показанную на рис. 2B; В парасагиттальный срез дорсальной $\mathrm{CBZ}$, прилежащей к дорсальным продольным мышцам (как это показано на рис. 2A); квадратом обозначена область, показанная на рис. 4A; C - парасагиттальный срез вентральной CBZ, прилежащей к вентральным продольным мышцам; D - горизонтальный срез латеральной CBZ, прилежащей к вентральным продольным мышцам; E - парасагиттальный срез вентральной CBZ, раположенной под брюшной нервной цепочкой; стрелка указывает на кутикулярное утолщение.

Обозначения: a - ацикула; се - эпидермис гребня; cm - мышцы гребня; ct - субэпидермальная соединительная ткань; cu - базальная кутикула; dm - дорсальные продольные мышцы; е - не аподермный эпидермис; ес эпикутикула; in - кишечник; $\mathrm{n}$ - ядро; pm - мускулатура параподий; se - эпидермис над гребнем; sm мускулатура над гребнем; vm - вентральные продольные мышцы; vnc - брюшная нервная цепочка. Масштаб: А - 0,4 мм; В, Е - 40 мкм; С, D - 20 мкм. 


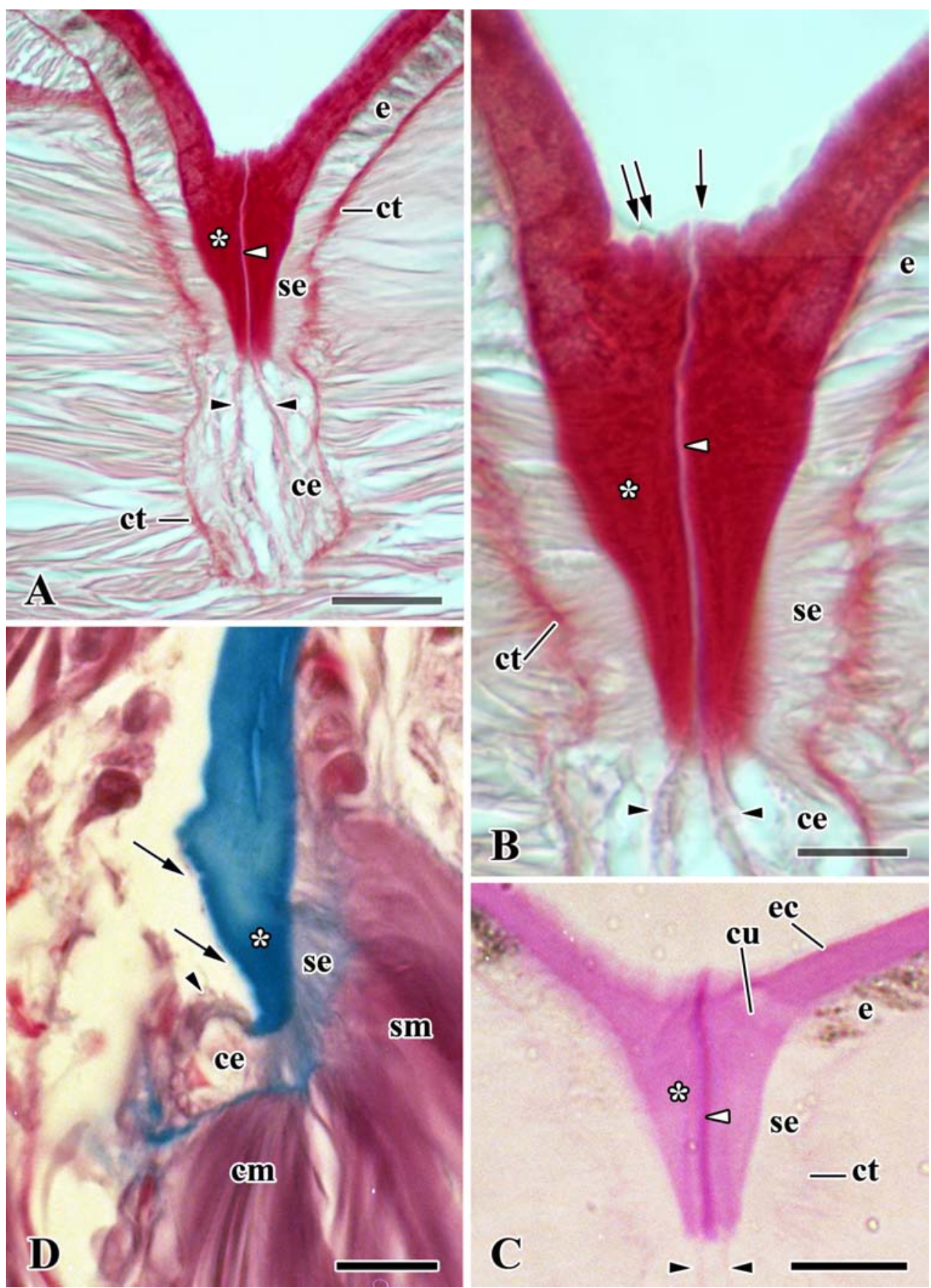

Fig. 3. Histology and histochemistry of the trunk cuticular breakage zone (CBZ) and adjacent structures of Harmothoe impar. In all micrographs the anterior end of the animal is towards the right; asterisks indicate cuticular apodeme; and black arrowheads indicate crestal sheets of tendon cells. A, B - parasagittal section of dorsal CBZ stained with picrosirius red; single arrow indicates main externally projecting ridge; double arrows indicate minor parallel ridges and grooves; $\mathrm{C}$ - parasagittal section stained with periodic acidSchiff; the CBZ was more strongly stained than other regions of the cuticle and all epidermal regions were 
Table 1. Staining properties of the cuticular breakage zone and adjacent histological components of Harmothoe impar.

Таблица 1. Особенности окраски зоны кутикулярного разлома и прилежащих к ней структур y Harmothoe impar.

\begin{tabular}{|c|c|c|c|c|}
\hline \multirow{3}{*}{ Component } & \multicolumn{4}{|c|}{ Stain } \\
\hline & \multicolumn{2}{|c|}{ Milligan's trichrome } & \multirow{2}{*}{ Picrosirius red } & \multirow{2}{*}{ PAS } \\
\hline & Aniline blue & Acid fuchsin & & \\
\hline Cuticular breakage zone & $-/+$ & - & $-1+$ & +++ \\
\hline Epicuticle & - & - & - & +++ \\
\hline Basal cuticle & +++ & - & +++ & ++ \\
\hline Subepidermal connective tissue & ++ & - & ++ & \pm \\
\hline Subcrestal tendon cells & + & \pm & - & - \\
\hline Crestal tendon cells & ++ & +++ & - & \pm \\
\hline
\end{tabular}

Symbols: +++ — strongly stained; ++ - moderately stained; + — weakly stained; \pm - staining just discernible; - - unstained; -/+ — some parts unstained, other parts weakly stained.

Символами обозначены: +++ — сильное окрашивание; ++ — умеренное окрашивание; + - слабое окрашивание; \pm - едва различимое окрашивание; - — не окрашено; - /+ — некоторые части не окрашены, другие - слабо окрашены.

tive tissue layer to the subcrestal apodemal epidermis on the anterior and posterior sides of the apodeme, and to the anterior and posterior sides of the crestal apodemal epidermis (Figs 2B-D, 3D).

After autotomy, the fracture surface of the CBZ is relatively smooth and in parasagittal sections has a undulating profile resembling that of intact CBZs. The crestal apodemal epidermis is torn apart during autotomy. Each half apodeme thus retains a half portion of the crestal epidermis, including a single sheet of acido- philic cells that remains attached to the apodemal half-crest (Fig. 3D).

\section{Transmission electron microscopy}

The transmission electron microscopic investigation was aimed specifically at describing the ultrastructure of those components that link the longitudinal muscle to the anterior and posterior subcrestal surfaces of the cuticular apodeme, since there has been uncertainty about the identity of these components (Clark, Richardson, 1967; Daly, 1973).

unstained; note the pigment granules in the non-apodemal epidermis; D - parasagittal section of proximal (retained) portion of lateral apodeme and adjacent structures after autotomy (compare with intact lateral apodeme in Fig. 2D); stained with Milligan's trichrome; arrows indicate fracture surface of ruptured CBZ. Abbreviations: ce — crestal epidermis; $\mathrm{cm}$ - crestal muscle fibres; ct — subepidermal connective tissue; cu — basal cuticle; e - non-apodemal epidermis; ec - epicuticle; se — subcrestal epidermis; sm — subcrestal muscle fibres. Scale bars: A, C, D $-20 \mu \mathrm{m} ; \mathrm{B}-10 \mu \mathrm{m}$.

Рис. 3. Гистология и гистохимия кутикулярной зоны разлома туловища (CBZ) и прилежащих структур у Harmothoe impar. На всех фотография передний конец тела животного расположен справа. Звездочками обозначены кутикулярные аподемы; черными наконечниками указаны пластинки гребня сухожильных клеток; белыми наконечниками указана CBZ. A, В - парасагиттальный срез дорсальной CBZ окрашенной пикросириусом красным; единичная стрелка указывает на наиболее выступающий кутикулярный гребень; двойные стрелки показывают меньшие параллельные гребни и желобки; C - парасагиттальный срез, окрашенный при помощи ШИК-реакции; CBZ была ярче окрашена по сравнению с другими участками кутикулы, в то время как эпидермис вовсе остался не окрашенным; обратите внимание на пигментные гранулы в не аподемном эпидермисе; D - парасагиттальный срез проксимального (созхранившегося) участка латеральной аподемы и прилежащих структур после автотомии (сравните с латеральной аподемой на рис. 2D); срез окрашен трихромом Миллигана; стрелками обозначены и указывают разрывы поверхности CBZ.

Обозначения: се - эпидермис гребня; cm - мышцы гребня; ct - субэпидермальтная соединительная ткань; $\mathrm{cu}$ - базальная кутикула; e - не аподемный эпидермис; ec - эпикутикула; se - эпидермис под гребнем; sm мышцы под гребнем. Масштаб: A, C, D - 20 мкм; B - 10 мкм. 
The cells of the subcrestal apodemal epidermis contain large numbers of fibrous structures that extend from the basal to apical sides of the cells (Fig. 4A). The fibrous structures are bundles of tightly packed tonofilaments that have a diameter of around $8 \mathrm{~nm}$ and a beaded appearance with a periodicity of around $11 \mathrm{~nm}$ (Fig. $4 \mathrm{~B}, \mathrm{C})$. The presence of these tonofilament bundles explains the fibrous appearance of the subcrestal epidermis when viewed in the light microscope. The cells form an interdigitating junction with the apodemal cuticle and the tonofilament bundles are attached to hemidesmosome-like structures at the base of the cellular projections (Fig. 4B). The tonofilament bundles are also attached to hemidesmosome-like structures at the basal edge of the epidermal cells (Fig. 5A). Other organelles are present between the tonofilament bundles, including Golgi complexes and vacuoles of various sizes and with contents of varying electron opacity (Fig. 4B).

The connective tissue between the subcrestal epidermis and the adjacent longitudinal muscle fibres consists of a layer of cross-banded collagen fibrils (diameter around $70 \mathrm{~nm}$; periodicity around $50 \mathrm{~nm}$ ) whose longitudinal axes are parallel to the basal surface of the cells but aligned in different directions within that plane (Fig. 5B). The layer of collagen fibrils is sandwiched between the finely granular laminae densae of the epidermal and muscle cells (Fig. 5A, B).

\section{Discussion}

Like other polynoids, $H$. impar can autotomise posterior portions of the trunk. Whilst it was demonstrated previously that this process involves a localised breakage zone within the external cuticle of the integument (Daly, 1973), the present investigation has identified additional structural features of the cuticle, epidermis and musculature that appear to be related to the capacity for autotomy.

\section{Cuticle}

The cuticle of polynoids and other annelids comprises a thin outer epicuticle and much thicker basal layer, the latter consisting predominantly of unbanded collagen fibrils (Richards, 1984; Storch, 1988; Gardiner, 1992), which explains its strong affinity for connective tissue stains, such as the aniline blue of Milligan's trichrome and picrosirius red. In sections stained by these two methods the CBZ is visible as an unstained or weakly stained gap, indicating that there is a discontinuity in the collagenous framework. The strong staining by the PAS method suggests that the collagenous component is at least partly replaced by an electrostatically neutral glycoprotein (Cook, 1990) and therefore that the tensile strength of the material comprising the CBZ is lower than that of the adjacent cuticle (tensile strength $=$ maximal tensile force that can be applied to a structure before it breaks/cross-sectional area of the structure: Vogel, 2013).

cell-cuticle junction (arrows); C - more magnified image of a tonofilament bundle, showing the beaded appearance of the tonofilaments (arrowhead).

Abbreviations: ct — subepidermal connective tissue; cu — basal cuticle; $\mathrm{g}$ - Golgi complex; $\mathrm{dm}$ - dorsal longitudinal muscle; $\mathrm{n}-$ nucleus; tf - tonofilament bundle. Scale bars: $\mathrm{A}-2 \mu \mathrm{m}$; B $-0.5 \mu \mathrm{m} ; \mathrm{C}-0.1 \mu \mathrm{m}$.

Рис. 4. Ультраструктура эпидермиса под гребнем аподемного эпителия Harmothoe impar (TEM). A участок, соответствующий области в квадрате на рис. 2В и демонстрирующий отдельные эпидермальные клетки, которые проходят от кутикулы аподемы (в левом нижнем углу) до субэпидермальной соединительной ткани (в правом верхнем углу) и содержат многочисленные пучки тонофиламентов; В - апикальный участок эпидермальных клеток, прилежащих к кутикуле аподемы и содержащих пучки тонофиламентов, крепящихся субмембранной пластинке полудесмосомо-подобными контактами (показаны стрелками); C - пучки тонофиламентов на большом увеличении: наконечником показаны электронно-плотные скопления («бусины»), ассоциированные с тонофиламентами.

Обозначения: ct - субэпидермальная соединительная ткань; сu — базальная кутикула; $\mathrm{g}$ - комплекс Гольджи; $\mathrm{dm}$ - дорсальные продольные мышцы; $\mathrm{n}$ - ядро; $\mathrm{tf}$ - пучки тонофиламентов. Масштаб: А - 2 мкм; В - 0,5 мкм; С $-0,1$ мкм. 

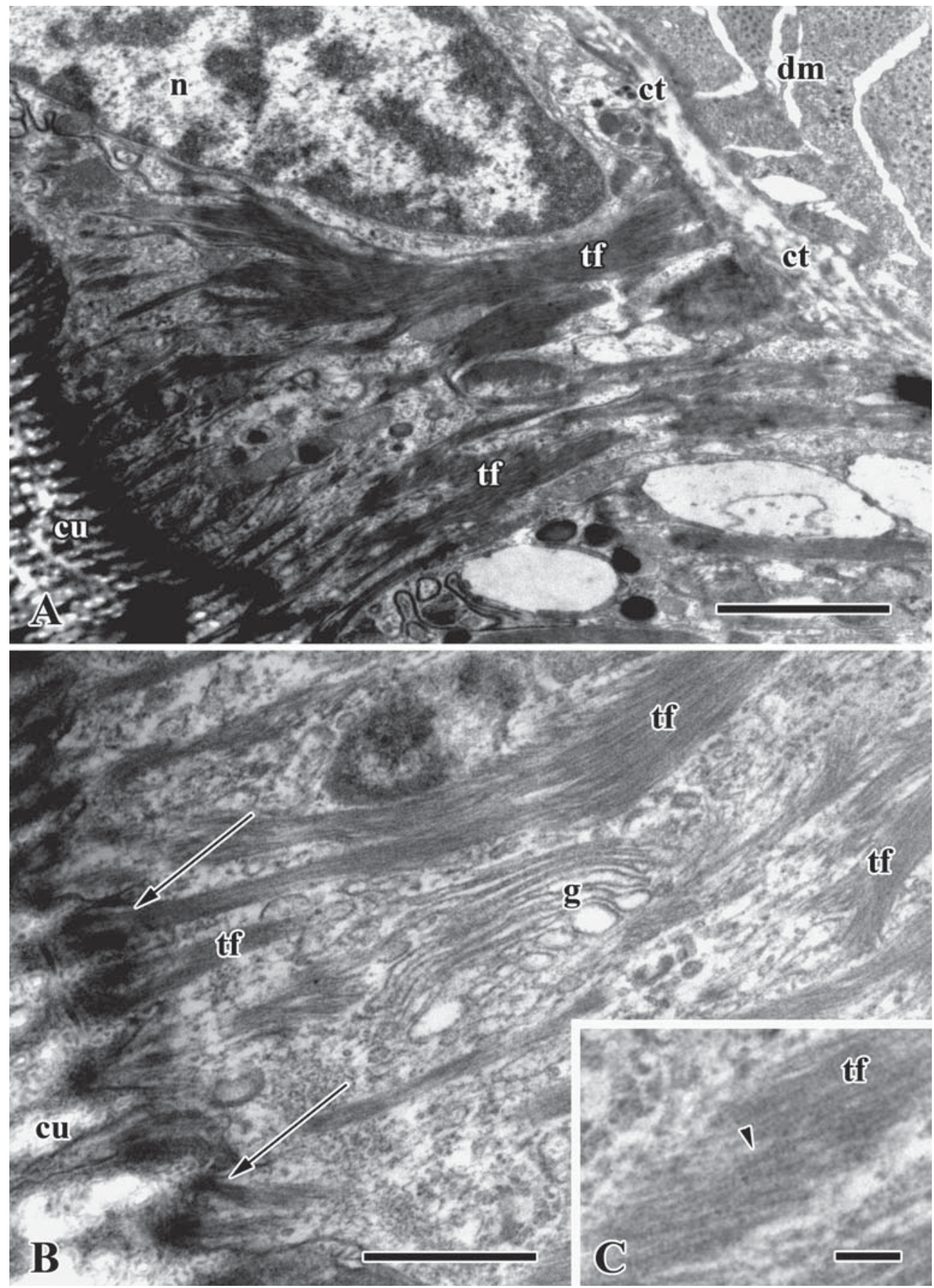

Fig. 4. Ultrastructure of the subcrestal apodemal epidermis of Harmothoe impar (TEM). A - area equivalent to that outlined by the box in Fig. 2B, showing a single epidermal cell, which extends from the apodemal cuticle (on the lower left) to the subepidermal connective tissue (on the upper right) and contains many tonofilament bundles; B - apical region of an epidermal cell adjacent to the apodemal cuticle, with tonofilament bundles attached to the subplasmalemmal plaques of hemidesmosome-like structures at the 
The CBZ passes through a circumferential thickening of the cuticle which projects internally. The presence of these internal ridges in the trunk cuticle of a range of polynoids was first noted by Clark \& Richardson (1967) who called them "apodemes" due to their resemblance to the cuticular apodemes of arthropods, which support internal organs and provide attachment points for muscles (Heming, 2003). Regarding their functional significance, Lawry (1971) suggested that those longitudinal muscle fibres that are connected to the apodemes shorten individual trunk segments, whereas those fibres that continue between segments are responsible for trunk flexion. Daly (1973), on the other hand, observing that the CBZs of the parapodia, elytrophores and other structures also pass through cuticular ridges, proposed that the apodemes are "primarily autotomy planes" and that autotomy is achieved by the abrupt contraction of the longitudinal muscle fibres that are attached to them. However, in H. impar, even in dorsal, ventral and lateral locations between the longitudinal muscles, where no longitudinal muscle fibres are connected to the cuticle, the CBZ passes through a cuticular thickening (though its salience is lower than in locations adjacent to the muscles). Furthermore, the cuticular thickening comprises both the internally projecting apodeme and a less prominent ridge that projects externally into the intersegmental groove. The cuticular thickening therefore has a functional significance that is additional to its role as an attachment point for muscle fibres. This is probably related to the presence of the CBZ and the need to reduce the risk of its accidental fracture by tensile forces generated during normal activities.
First, the thickening of the cuticle and consequent increase in cross-sectional area at the CBZ will at least partly compensate for the lower tensile strength of its constituent material and increase the resistance of the CBZ to tensile forces acting perpendicularly to its transverse plane $($ since breaking force $=$ tensile strength $\times$ cross-sectional area; Fig. 6A-C). Second, the externally projecting ridge will prevent stress concentration at the external edge of the CBZ. When the trunk of a scaleworm bends, for example during locomotion (Lawry, 1970), the intersegmental grooves on the convex side of the trunk are under tension, which results in a concentration of stress at the deepest point in each groove, i.e. at the external edge of the CBZ (Fig. $6 \mathrm{~A}, \mathrm{~B})$. Since the fracture of a structure is initiated by a concentration of stress at a molecular weakness (Buehler, Ackbarow, 2007), there is therefore a danger that the CBZ could be ruptured accidentally. However, due to the externally projecting cuticular ridge, stress is deflected away from the edge of the CBZ to the grooves on the anterior and posterior sides of the ridge (Fig. 6C). Stress concentration on either side of the ridge will also be dissipated by the presence of multiple, rather than single, grooves, a design that is used to alleviate the stress concentration effect of grooves in manmade load-bearing structures (Hearn, 1985; Pilkey, 2004).

The same mechanical functions may be served by the thickening of the cuticle at the elytrophoral CBZ of the polynoid Alentia gelatinosa (Wilkie, 2011) and the thickening of the collagenous dermis at the autotomy plane of reptile tails, where the breakage zone consists of

\footnotetext{
Abbreviations: cfl — collagen fibril (longitudinal section); $\mathrm{cft}$ — collagen fibril (transverse section); $\mathrm{cp}$ — cytoplasmic plaque; ld - lamina densa; lu — lamina lucida; dm — dorsal longitudinal muscle; pl — plasma membrane; tf — tonofilaments. Scale bars: A, B $-0.2 \mu \mathrm{m}$.

Рис. 5. Ультраструктура эпидермиса аподемы, расположенного под гребнем у Harmothoe impar (TEM). A - контакт между базальным краем эпидермальной клетки (слева) и субэпидермальной соединительной тканью (справа): показаны межклеточные тонофиламенты, крепящиеся к субмембранной полудесмосомо-подобной пластинке, и поперечно исчерченные коллагеновые волокна, связанные с базальной пластинкой эпидермиса; В - контакт между субэпидермальной соединительной тканью (слева) и продольными мышцами (справа).

Обозначения: cfl — коллагеновое волокно (продольный срез); cft — коллагеновое волокно (поперечный срез); cp — цитоплазматическая пластинка; ld - базальная пластинка; lu - ламина люцида; dm - дорсальная продольная мускулатура; $\mathrm{pl}$ - плазматическая мембрана; tf — тонофиламенты. Масштаб: А, B — 0,2 мкм.
} 

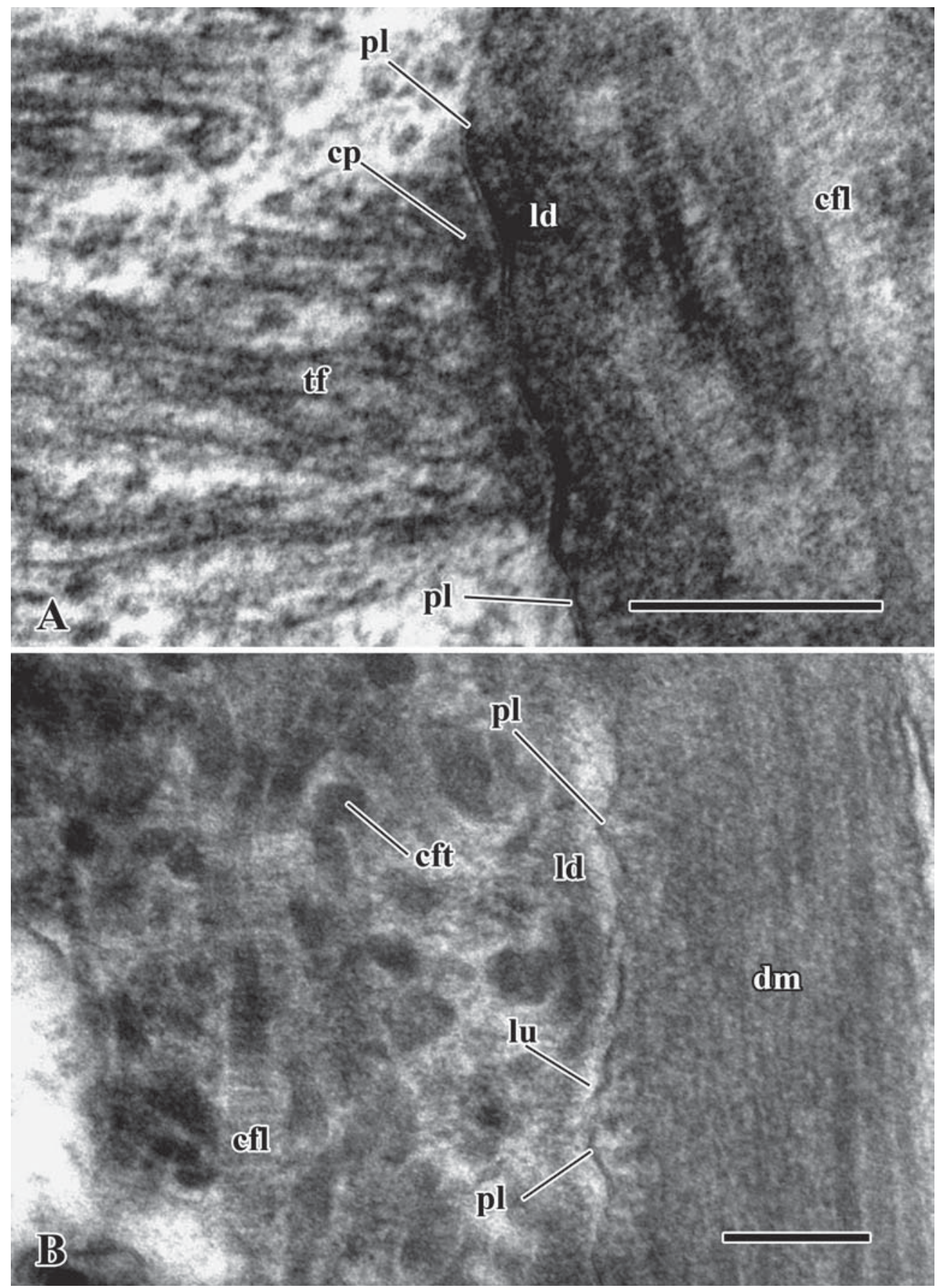

Fig. 5. Ultrastructure of the subcrestal apodemal epidermis of Harmothoe impar (TEM). A - junction between the basal edge of an epidermal cell (on the left) and the subepidermal connective tissue (on the right), showing intracellular tonofilaments attached to a subplasmalemmal hemidesmosome-like cytoplasmic plaque and cross-banded collagen fibrils adjacent to the epidermal lamina densa; B - junction between the subepidermal connective tissue (on the left) and longitudinal muscle (on the right). 


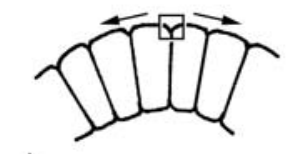

A

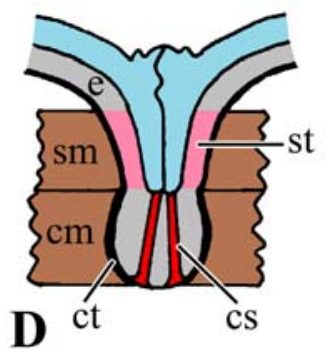

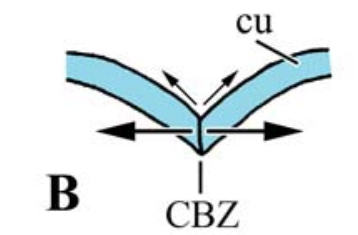

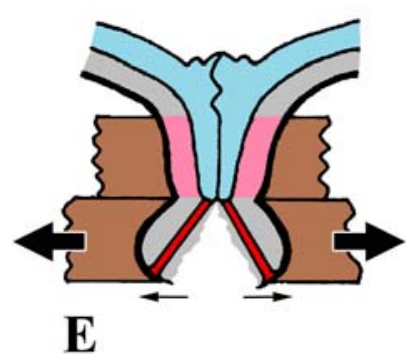

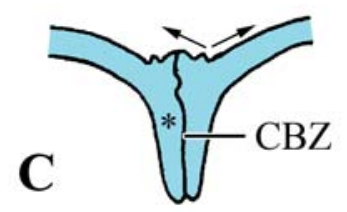

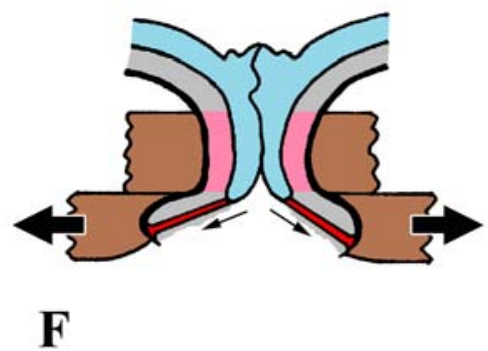

Fig. 6. Diagrams of the cuticular breakage zone (CBZ) and adjacent structures of Harmothoe impar. A bending trunk, showing that intersegmental grooves on the convex side of a bend are under tension (arrows); box indicates area enlarged in Fig. 6 B-F. Fig. 6 B-F represent parasagittal sections of dorsal CBZ and adjacent structures. B - imaginary intersegmental groove lacking adaptations for reducing the risk of accidental CBZ fracture, showing that when the groove is under tension the CBZ is subjected to tensile forces acting perpendicularly to its transverse plane (large arrows) and there is a concentration of tensile stress at the external edge of the CBZ (small arrows). C - adapted intersegmental groove as observed in H. impar, showing that the apodeme (asterisk) increases the cross-sectional area of the CBZ and that the externally projecting ridge deflects stress concentration (small arrows) away from the CBZ. D-F — hypothesised mechanism of cuticular fracture. D - intact condition before autotomy. E - at autotomy, crestal muscle fibres begin to contract (large arrows) and rupture the subepidermal connective tissue at the adaxial side of the crestal epidermis (small arrows). F — continuing contraction of the crestal muscle fibres results in opposing tensile forces being transmitted through the crestal sheets to the basal edge of the CBZ (small arrows) and initiating its fracture.

Abbreviations: CBZ — cuticular breakage zone; cm — crestal muscle fibres; cs — crestal sheets of tendon cells; ct — subepidermal connective tissue; cu — cuticle; e - epidermis; sm — subcrestal muscle fibres; st — subcrestal tendon cells.

Рис. 6. Схема строения кутикулярной зоны разлома (CBZ) и прилежащих структур у Harmothoe impar. A - изогнутый участок тела животного, показывающий, что на выпуклой стороне, между сегментами тела имеются желобки, в которых возникает напряжение (направляюще напряжения показаны стрелками). Квадратом обозначена область, показанная на рис. 6B-F. B-F - схемы парасагиттального среза дорсальной CBZ и прилежащих структур; В — гипотетический межсегментный желобок, лишенный морфологических структур, предотвращающих риск случайного разрыва CBZ. Показано, что когда желобок находится под напряжением, CBZ является местом приложения тянущей силы, действующей перпендикулярно поперечной плоскости CBZ (направление силы показано большими стрелками) и приводящей к возникновению тянущего момента на внешней поверхности наружного края CBZ (маленькие стрелки); C - генерализованная схема межсегментного желобка: показано, что появление аподемы (отмечена звездочкой) увеличивает поперечный размер CBZ и выдающийся наружу гребень приводит к изменению направления (показано маленькими стрелками) напряжения прочь от CBZ; D-F — гипотетический механизм разрыва кутикулы; D интактное состояние перед автотомией. E - автотомия, мышцы гребнясокращаются (направление силы сокращение показано большими стрелками) и разрывают субэпидермальную соединительную ткань по направлению к оси эпидермиса гребня (маленькие стрелки); F — продолжающееся сокращение мышц гребня приводит к возникновению напряжения на базальной крае CBZ (маленькие стрелки), что приводит к разрыву.

Обозначения: CBZ - кутикулярная зона разлома; $\mathrm{cm}$ - мышцы гребня; cs — пластинки в сухожильных клетках креста; ct - субэпидермальная соединительная ткань; сu — кутикула; e — эпидермис; sm - мускулатура под гребнем; st - сухожильные клетки под крестом. 
a thin cellularised layer (Seligmann et al., 2008; Sanggaard et al., 2012).

\section{Epidermis and subepidermal connective tissue}

The histological appearance of the subcrestal epidermal cells that link longitudinal muscle fibres to the anterior and posterior sides of the apodeme differs from that of non-apodemal epidermal cells. This was first noted by Clark and Richardson (1967) who were uncertain as to whether or not they were "musculo-epithelial cells", whilst Daly (1973) labelled them as "muscle insertions" in his Fig. 3B but provided no cytological information on them. The present investigation has shown that these cells are characterised by the presence in their cytoplasm of prominent bundles of tonofilaments that extend between hemidesmosomes at the basal cell membrane and at the shoulders of the apical projections into the apodemal cuticle. Such tonofilament-rich epithelial cells connect muscles to cuticular structures in other annelids and are known as tendon cells (Jouin, 1978; Bubel, 1983; Storch, 1988; Wilkie, 2011). The tonofilament bundles are likely to possess relatively high mechanical stiffness (Sanghvi-Shah, Weber, 2017), which will enable them to efficiently transmit muscular force from the basal hemidesmosomes to the apical hemidesmosomes and the adjacent cuticle.

Contractile force is not transmitted directly from the longitudinal muscle fibres to the tendon cells, but via the intercalated subepidermal connective tissue, which consists largely of crossbanded collagen fibrils. A similar layer of collagen fibrils forming a "myotendon zone" occurs between the tendon cells and myocytes at other anatomical locations in annelids (Bubel, 1983; Wilkie, 2011), but is not always present (Jouin, 1978).

The epidermis at the crest of the apodeme includes two prominent sheets of cells that are attached to the crest on the anterior and posterior edges of the CBZ and extend to the subepidermal connective tissue. The latter is well developed at the insertion regions of these cells and is very thin between the insertion regions. The cellular sheets consist of tendon cells, since their intense acidophilia indicates the presence of tonofilaments, as was shown for the tendon cells at the elytrophoral CBZ of Alentia gelatinosa (Wilkie, 2011). The different staining properties of the crestal tendon cells, which are mainly acidophilic, and the mainly basophilic subcrestal tendon cells may be due to differences in the composition of the intermediate filament proteins that constitute their tonofilaments and may reflect differences in the mechanical functioning of the two cell types (Sanghvi-Shah, Weber, 2017). A similar distinction between the staining properties of the crestal and subcrestal tendon cells occurs at the trunk autotomy plane of Harmothoe extenuata and $H$. imbricata, but not at that of Alentia gelatinosa in which both cell types are mainly acidophilic (Wilkie, pers. obs.).

A cluster of circumferentially orientated acidophilic fibres is present at the basal edge of the crestal epidermal cells located between the insertion areas of the two sheets of tendon cells. Whilst the intense acidophilia of these fibres suggests that they are tonofilament bundles, their functional significance is not clear. Since they are adjacent to a very thin, and therefore mechanically fragile, region of subepidermal connective tissue, their role may be to increase the resistance of the overlying crestal epidermis to tensile forces acting in a circumferential direction and thus prevent accidental damage to the epidermis during locomotion and other activities. They may be related to the non-muscular "circumferential restraining fibres" which Smith (1957) described as lying in the basement membrane of the body wall of nereids.

\section{Musculature and the mechanism of cutic- ular fracture}

An outer layer of longitudinal muscle fibres extends between adjacent intersegmental apodemes. One subset of these fibres is attached to the subcrestal epidermis on the anterior and posterior sides of the apodeme and another, more internally located, subset is attached to the anterior and posterior sides of the inflated crestal epidermis. Daly (1973) suggested that the contraction of the longitudinal muscle fibres 
attached to the apodemes effected fracture of the $\mathrm{CBZ}$ at autotomy, but he did not distinguish between the subsets attached to the crestal and subcrestal epidermis respectively.

As argued above, because it represents a discontinuity in the collagenous framework of the cuticle, the CBZ is a plane of mechanical weakness. It was also explained above that the most efficient (i.e. energy-sparing) way to initiate the fracture of a plane of weakness is to concentrate tensile stress at one edge of the plane (Buehler, Ackbarow, 2007). Contraction of the subcrestal muscle fibres connected to the anterior and posterior sides of an apodeme would not achieve such an effect, since the apodemal insertion areas of the subcrestal tendon cells do not reach the basal edge of the CBZ. However, it is notable that the two sheets of crestal tendon cells are attached to the crest of the apodeme closely adjacent to, and on either side of, the CBZ. In histological sections of intact autotomy planes these sheets are aligned along, or close to, the radial axis of the apodeme, i.e. they are orthogonal, or nearly orthogonal, to the longitudinal axis of the muscles (Fig. 6D). In such an orientation, pulling forces transmitted through them to the apodemal crest would generate little if any tension across the edge of the CBZ. To apply significant tension, the sheets would need to be angled more obliquely. Such a change in orientation could be achieved by contraction of the crestal muscle fibres.

It is hypothesised herein that at trunk autotomy fracture of the cuticle is initiated by the simultaneous contraction of the crestal muscle fibres that are attached to the anterior and posterior sides of the crestal epidermis. The first effect of this contraction is to stretch and rupture the thin region of the subepidermal connective tissue between the basal insertion areas of the crestal tendon cells (Fig. 6E). As crestal muscle contraction continues, the two sheets of crestal tendon cells are rotated abaxially, becoming increasingly aligned with the crestal muscle fibres, and thereby transmitting opposing pulling forces to the CBZ. When the imposed stress exceeds the tensile strength of the CBZ, its edge is ruptured (Fig. 6F). Having been initiated by contraction of the crestal muscle fibres alone,
CBZ fracture may be completed by contraction of both the crestal and subcrestal muscle fibres. This hypothesised mechanism resembles that proposed for cuticular fracture at the elytrophoral autotomy plane of Alentia gelatinosa, in that it depends on the transmission of opposing forces by tendon cells attached to either side of the CBZ. However, at the elytrophoral autotomy plane, muscle fibres are attached to tendon cells on only one side of the CBZ, the force transmitted by the tendon cells on the other side being generated by a hydrostatic mechanism activated by the main musculature of the elytrophoral wall (Wilkie, 2011).

The above hypothesis implies that (1) the specific role of the crestal muscle fibres is to act as an autotomiser muscle that contracts only at autotomy and (2) the main function of the subcrestal muscle fibres is to effect normal trunk movements such as segment shortening, as suggested by Lawry (1971). It would be interesting to know if such a functional differentiation is reflected in the pattern of segmental innervation. Within each trunk segment are there separate motor pathways to the crestal and subcrestal groups of myocytes in each of the four longitudinal muscles?

\section{Conclusions}

The external cuticle and adjacent structures at the trunk autotomy plane of $H$. impar exhibit features that promote cuticular fracture at autotomy and other features that reduce the risk of fracture occurring accidentally in inappropriate circumstances. These features are summarised in Table 2. It is to be expected that a combination of features promoting and features preventing fracture will be present at any autotomy plane where the detachment of an anatomical structure depends on the mechanical disruption of one or more breakage zones with constitutively weaker material properties.

This investigation dealt mainly with the CBZ and adjacent epidermis. However, the trunk autotomy plane of polynoids passes through a range of anatomical components including the four longitudinal muscles, intestine, ventral nerve 
Table 2. Summary of features promoting and preventing cuticular fracture at the trunk autotomy plane of Harmothoe impar and their putative functional significance.

Таблица 2. Структуры, участвующие в стимуляции и предотвращении разрыва кутикулы при автотомии туловища у Harmothoe impar, и их предполагаемое функциональное назначение.

\begin{tabular}{|l|l|}
\hline Feature & Functional significance \\
\hline Promoting fracture & Restricts fracture to predictable plane \\
\hline Cuticular breakage zone (CBZ) & Generate forces that initiate cuticular fracture \\
\hline Crestal muscle fibres & $\begin{array}{l}\text { Transmit contractile force to basal edge of } \\
\text { CBZ }\end{array}$ \\
\hline Crestal tendon cells & $\begin{array}{l}\text { Acts as pre-weakened breakage zone which } \\
\text { facilitates division of crestal epidermis }\end{array}$ \\
\hline $\begin{array}{l}\text { Thin subepidermal connective tissue } \\
\text { layer on adaxial side of crestal epidermis }\end{array}$ & $\begin{array}{l}\text { Compensates for reduced tensile strength of } \\
\text { CBZ constituent material }\end{array}$ \\
\hline Preventing fracture & $\begin{array}{l}\text { Diverts tensile stress away from external edge } \\
\text { of CBZ during trunk bending }\end{array}$ \\
\hline CBZ crosses cuticular thickening & $\begin{array}{l}\text { Dissipate stress on either side of CBZ during } \\
\text { trunk bending }\end{array}$ \\
\hline $\begin{array}{l}\text { CBZ external edge is at crest of } \\
\text { circumferential external ridge }\end{array}$ & Increases resistance to shearing forces \\
\hline $\begin{array}{l}\text { Circumferential corrugations on distal } \\
\text { and proximal sides of external ridge }\end{array}$ & \\
\hline CBZ has undulating profile & \\
\hline
\end{tabular}

cord, and ventral and dorsal blood vessels. It is likely that in all of these there are adaptations for expediting breakage and localising damage at autotomy, as has been found in the various organs and tissues transected by the autotomy planes of other anatomically complex structures such as lizard tails (Sheppard, Bellairs, 1972) and brittlestar arms (Wilkie, 1978). The characterisation of such adaptations is necessary for understanding fully the link between autotomy and regeneration. Many, if not most, regeneration events occurring in polynoids and other annelids in the natural environment follow autotomy and in at least some species autotomy is a necessary prelude to normal regeneration (Kawamoto et al., 2005). It is likely, therefore, that there are cellular and/or molecular features at autotomy planes that facilitate the rapid restoration of normal structure and function. Current ignorance of these features (see Bely, 2014) indicates the need for thorough morphological, cell biological and molecular analyses of autotomy planes in polynoids and other annelids.

Acknowledgements. This investigation benefitted from financial support and laboratory facilities provided by Glasgow Caledonian University. I am grateful to two anonymous reviewers whose suggestions greatly improved the paper.

\section{References}

Beesley P.L., Ross G.B., Glasby C.J. (eds.). 2000. Polychaetes and allies. The southern synthesis. Fauna of Australia. Vol.4A. Polychaeta, Myzostomida, Pogonophora, Echiura, Sipuncula. Melbourne: CSIRO Publishing. 465p.

Bely A.E. 2014. Early events in annelid regeneration // Integr. Comp. Biol. Vol.54. P.688-699.

Bubel A. 1983. An ultrastructural investigation of muscle attachment in the opercular filament of a polychaete annelid // Tissue Cell. Vol.15. P.555-572.

Buehler M.J., Ackbarow T. 2007. Fracture mechanics of protein materials // Mater. Today. Vol.10. P.46-58.

Clark R.B., Richardson E. 1967. Apodemes and tonofibrillae in polychaetes // Bull. Soc. Zool. France. T.92. P.207-212.

Cook H.C. 1990. Carbohydrates // J.D. Bancroft, A. Stevens (eds.). Theory and practice of histological techniques. Edinburgh: Churchill Livingstone. P.177-213.

Daly J.M. 1973. Segmentation, autotomy and regeneration of lost posterior segments in Harmothoe imbricata (L.) (Polychaeta: Polynoidae) // Mauri Ora. Vol.1. P.17-28.

Gardiner S.L. 1992. Polychaeta: general organization, integument, musculature, coelom, and vascular system // F.W. Harrison, S.L. Gardiner (eds.). Annelida. Microscopic anatomy of invertebrates. Vol.7. NewYork: Wiley-Liss. P.19-52.

Hausen H. 2005. Comparative structure of the epidermis in polychaetes // Hydrobiologia. Vol.535/536. P.2535.

Hearn E.J. 1985. Mechanics of materials. Vol.2. (2nd edn.). Oxford: Pergamon Press. 542 p. 
Heming B.S. 2003. Insect development and evolution. Ithaca: Cornell University Press. 444 p.

Humason G.L. 1979. Animal tissue techniques (4th edn.). San Francisco: Freeman. 661 p.

Jouin C. 1978. Anatomical and ultrastructural study of the pharyngeal bulb in Protodrilus (Polychaeta, Archiannelida). I. Muscles and myo-epithelial junctions // Tissue Cell. Vol.10. P.269-287.

Kallman F., Wessells N.K. 1967. Periodic repeat units of epithelial cell tonofilaments // J. Cell Biol. Vol.32. P.227-231.

Kawamoto S., Yoshida-Noro C., Tochinai S. 2005. Bipolar head regeneration induced by artificial amputation in Enchytraeus japonensis (Annelida, Oligochaeta) // J. Exp. Zool. Vol.303A. P.615-627.

Lawry J.V. 1970. Mechanisms of locomotion in the polychaete, Harmothoë//Comp. Biochem. Physiol. Vol.37. P.167-179.

Lawry J.V. 1971. The parapodial and segmental musculature of Harmothoë imbricata // J. Morph. Vol.135. P.259-272.

Livermore J., Perreault T., Rivers T. 2018. Luminescent defensive behaviors of polynoid polychaete worms to natural predators // Mar. Biol. Vol.165. No.149. doi: org/10.1007/s00227-018-3403-2.

López E., San Martín G. 1996. A new species of (Polychaeta: Polynoidae) from the Chafarinas Islands (Alboran Sea, Western Mediterranean) // Cah. Biol. Mar. T.37. P.183-187.

Martin D., Britayev T.A. 1998. Symbiotic polychaetes: review of known species // Oceanogr. Mar. Biol. Ann. Rev. Vol.36. P.217-340.

Martin D., Britayev T.A. 2018. Symbiotic polychaetes revisited: an update of the known species and relationships (1998-2017) // Oceanogr. Mar. Biol. Ann. Rev. Vol.56. P.371-448.

McVean A.R. 1973. Autotomy in Carcinus maenas (Decapoda: Crustacea) // J. Zool. Vol.169. P.349-364.

Montes G.S., Junqueira L.C.U. 1991. The use of the picrosirius-polarization method for the study of the biopathology of collagen // Mem. Inst. Oswaldo Cruz. Vol.86. (Suppl. III). P.1-11.

Moore J.P. 1910. The polychaetous annelids dredged in the U.S.S. "Albatross" off the coast of southern California in 1904: II. Polynoidae, Aphroditidae and Segaleonidae// Proc. Acad. Nat. Sci. Philadelphia. Vol.62. P.328-402.

Nishi E., Tachikawa H. 1999. A new record of a commensal scale worm Medioantenna clavata Imajima, 1997 (Polychaeta: Polynoidae), from Ogasawara Islands, Japan // Nat. Hist. Res. Vol.5. P.107-110.

Paterson G.L.J., Glover A.G., Barrio Froján C.R.S., Whitaker A., Budaeva N., Chimonides J., Doner S. 2009. A census of abyssal polychaetes // Deep-Sea Research II. Vol.56. P.1739-1746.

Pilkey W.D. 2004. Formulas for stress, strain, and structural matrices (2nd edn.). Ch. 6. Stress concentration. New York: Wiley. P.255-305.

Richards K.S. 1984. Cuticle // J. Bereiter-Hahn, A.G. Matoltsy, K.S. Richards (eds.). Biology of the integument. Vol.1. Invertebrates. Berlin: Springer-Verlag. P.310-322.
Sanggaard K.W., Danielsen C.C., Wogensen L., Vinding M.S., Rydtoft L.M., Mortensen M.B., Karring H., Nielsen N.C., Wang T., Thøgersen I.B., Enghild J.J. 2012. Unique structural features facilitate lizard tail autotomy // PLoS ONE. Vol.7. No.12: e51803. doi: 10.1371/journal.pone.0051803.

Sanghvi-Shah R., Weber G.F. 2017. Intermediate filaments at the junction of mechanotransduction, migration, and development // Front. Cell Dev. Biol. doi.org/ 10.3389/fcell.2017.00081.

Schindler G. 1979. Funktionsmorphologische Untersuchungen zur Autotomie der Stabheuschrecke Carausius morosus Br. (Insecta: Phasmida) // Zool. Anz. Bd.203. S.316-326.

Seligmann H., Moravec J., Werner Y.L. 2008. Morphological,functional and evolutionary aspects of tail autotomy in the "living fossil" Sphenodon (Reptilia: Rhynchocephalia)// Biol. J. Linn. Soc. Vol.93. P.721743.

Sheppard L., Bellairs A.d'A. 1972. The mechanism of autotomy in Lacerta // Brit. J. Herpetol. Vol.4. P.276286.

Shultz J.W. 2000. Skeletomuscular anatomy of the harvestman Leiobunum aldrichi (Weed, 1893) (Arachnida: Opiliones: Palpatores) and its evolutionary significance // Zool. J. Linn. Soc. Vol.128. P.401-438.

Smith J.E. 1957. The nervous anatomy of the body segments of nereid polychaetes // Phil. Trans. R. Soc. B. Vol.240. P.135-196.

Storch V. 1988. Integument // W. Westheide, C.O. Hermans (eds.). The ultrastructure of Polychaeta. Microfauna Marina. Vol.4. P.13-36.

Vogel S. 2013. Comparative biomechanics (2nd edn.). Ch. 15. A matter of materials. Princeton: Princeton University Press. P.287-312.

Wake D.B., Dresner I.G. 1967. Functional morphology and evolution of tail autotomy in salamanders // J. Morphol. Vol.22. P.265-306.

Wilkie I.C. 1978. Functional morphology of the autotomy plane of the brittlestar Ophiocomina nigra // Zoomorphology Vol.91. P.289-305.

Wilkie I.C. 2001. Autotomy as a prelude to regeneration in echinoderms // Microscop. Res. Tech. Vol.55. P.369396.

Wilkie I.C. 2011. Functional morphology and biomechanics of cuticular fracture at the elytrophoral autotomy plane of the scaleworm Alentia gelatinosa (Annelida: Polynoidae) // Invertebrate Biology. Vol.130. P.129147.

Zhang Y., Sun J., Chen C., Watanabe H.K., Feng D., Zhang Y., Chiu J.M.Y., Qian P.Y., Qiu J.W. 2017. Adaptation and evolution of deep-sea scale worms (Annelida: Polynoidae): insights from transcriptome comparison with a shallow-water species // Sci. Rep. Vol.7. No.46205. doi: 10.1038/srep46205.

Zhang Y., Chen C., Qiu J.W. 2018. Sexually dimorphic scale worms (Annelida: Polynoidae) from hydrothermal vents in the Okinawa Trough: two new species and two new sex morphs // Front. Mar. Sci. Vol.5. No.112. doi: 10.3389/fmars.2018.00112.

Responsible editor E.N. Temereva 